\title{
LIFESTYLE RISK FACTORS IN THE DEVELOPMENT OF KIDNEY CANCER: A RUSSIAN EXPERIENCE
}

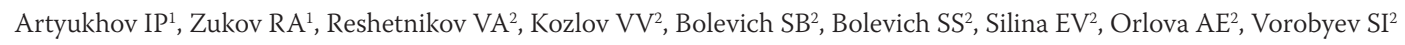
${ }^{1}$ Krasnoyarsk State Medical University, Moscow, Russia

${ }^{2}$ I.M. Sechenov First Moscow State Medical University, Moscow, Russia

\author{
STIL ŽIVOTA KAO FAKTOR RIZIKA ZA NASTANAK \\ KARCINOMA BUBREGA: ISKUSTVA IZ RUSIJE \\ Artyukhov IP ${ }^{1}$, Zukov RA ${ }^{1}$, Reshetnikov VA ${ }^{2}$ Kozlov VV ${ }^{2}$, Bolevich SB ${ }^{2}$, Bolevich SS ${ }^{2}$, Silina EV ${ }^{2}$, Orlova $\mathrm{AE}^{2}$, Vorobyev SI ${ }^{2}$ \\ ${ }^{1}$ Državni medicinski univerzitet Krasnojark, Moskva, Rusija \\ ${ }^{2}$ Prvi moskovski državni medicinski univerzitet Sečenov, Moskva, Rusija
}

\begin{abstract}
The objective of our study was the evaluation of major lifestyle risk factors for the development of renal cell carcinoma (RCC) and the assessment of chances of developing this disease among inhabitants in the region, in the presence of and with combinations of the studied risk factors. Risk factors for developing RCC that are associated with lifestyle (smoking, obesity and hypertension) were observed in 500 patients with RCC aged 30-64 years who were investigated at the Krasnoyarsk Oncology Dispensary (study group) and 858 participants in the Krai (control group). The results of our study showed that smoking increases the risk of developing RCC 2.9 times and arterial hypertension 3.3 times in men; in women, obesity and hypertension increased these risks 2.6 and 3.2 times, respectively. All three risk factors were combined in $13.6 \%$ of men and in $8.4 \%$ of women with RCC. Our data may be useful for the prevention, development of screening programmes and early diagnosis of RCC.
\end{abstract}

Keywords: risk factors, renal cell carcinoma, kidney cancer, smoking, obesity, arterial hypertension

\section{SAŽETAK}

Cilj ovog istraživanja bio je evaluacija najznačajnijih faktora rizika koji potiču od stila života na razvoj karcinoma bubrežnih ćelija (KBĆ) i procena šanse za razvoj bolesti u regionu, u zavisnosti od prisutnosti ispitivanih faktora rizika. Faktori rizika za razvoj karcinoma bubrežnih ćelija koji su povezani sa stilom života (upotreba nikotina, gojaznost $i$ hipertenzija) su posmatrani kod 500 pacijenata obolelih od karcinoma bubrežnih ćelija starosti 30-64 godina u Onkološkoj klinici Krasnojark (eksperimentalna grupa) $i$ 858 ispitanika u kontrolnoj grupi u Krai. Rezultati studije su pokazali da upotreba nikotina 2,9 puta, dok hipertenzija 3,3 puta povećava rizik za razvoj karcinoma bubrežnih ćelija kod muškaraca; sa druge strane kod žena gojaznost $i$ hipertenzija povećavaju ovaj rizik za 2,6 i 3,2 puta. Sva tri faktora rizika su bila prisutna kod 13,6\% muškaraca i 8,4\% žena sa karcinomom bubrežnih ćelija. Ovi podaci mogu biti od koristi za prevenciju bolesti, razvoj programa za skrining i ranu dijagnozu karcinoma bubrežnih ćelija.

Ključne reči: faktori rizika, karcinom bubrežnih ćelija, karcinom bubrega, upotreba nikotina, gojaznost $i$ hipertenzija

\section{INTRODUCTION}

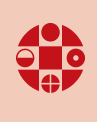

Renal cell carcinoma (RCC) is a multifactorial disease. Approximately 100 risk factors for the development of this malignant neoplasm have been described in the literature (1). However, in accordance with principles of evidence-based medicine, only three of these factors have been confirmed in large non-randomized, well-planned controlled trials (level of evidence: 2a): smoking, obesity and arterial hypertension (2). Smoking is a risk factor for development of RCC, as proven by the International Agency for Research on Cancer (3, 4). A large meta-analysis conducted in 24 centres showed that compared with non-smokers, there is a greater risk of developing RCC in ever-smokers. The risk of developing this SNR increases in proportion to the number of cigarettes smoked per day. Compared

to those who never smoked, people who smoke more than 20 cigarettes a day increase the risk of developing RCC by $60-$ $100 \%$. The risk of developing RCC decreases only 10 years after quitting smoking (5). On the other hand, regarding excess body weight, the relationship between increase in body mass index (BMI) and risk of RCC development has been proven, and this risk is more pronounced in women than in men and depends on the degree of obesity. Thus, for every $5 \mathrm{unit}\left(\mathrm{kg} / \mathrm{m}^{2}\right)$ increase in BMI, the risk of developing RCC increases by $24 \%$ in men and $34 \%$ in women $(6,7)$. The mechanism of this effect is associated with chronic hypoxia, insulin resistance development in tissues and compensatory hyperinsulinaemia, endocrine status changes with hyperproduction of adipokines, oestrogen, 
growth factors, immune response changes and cholesterol metabolism, increased lipid peroxidation and oxidative stress $(8,9)$. The association of arterial hypertension $(\mathrm{AH})$ and the means used for its treatment, with the development of RCC, has been established in a number of epidemiological studies (10-12). The biological mechanism of this connection is not fully understood but is most likely associated with chronic renal hypoxia, lipid peroxidation, and formation of free radicals $(13,14)$. The risk of $\mathrm{RCC}$ in patients with $\mathrm{AH}$ is increased by $60 \%$ according to one author (11), and another group of researchers (12) found a $24 \%$ increase in risk in women and $15 \%$ in men. To date, the role of antihypertensive drugs in the development of RCC has not been determined, but it has been established that controlled BP reduces the risk of developing $\mathrm{RCC}(11,12)$.

The aim of the study was to examine the major lifestyle risk factors for the development of RCC and to evaluate the chances of developing this disease among inhabitants of the region in the presence and combination of studied risk factors.

\section{MATERIALS AND METHODS}

The three major lifestyle-associated risk factors (smoking, obesity and hypertension) for the development of RCC were studied in 500 patients with RCC, age range 30-64 years old, at the Krasnoyarsk oncological dispensary (study group) and in 858 participants of the Krasnoyarsk Territory (control group). Study participants were from similar sex and age groups from a study of the main behavioural risk factors for the development of chronic non-communicable diseases within the framework of the targeted programme 'Prevention and control of socially significant diseases' (15). Evaluation of smoking-related indicators was carried out on the basis of questionnaire, which included questions about the existence of bad habits, quality of tobacco products, smoking experience and the number of cigarettes smoked per day. These questions are used in most major sociological studies on tobacco consumption in our region, Russia, Europe and the United States $(5,16,17)$.

Body weight estimation was carried out using body mass index (BMI), developed by Quetelet et al., and calculated by the formula ( $\mathrm{m}=$ body weight in $\mathrm{kg}$; $\mathrm{h}=$ growth in metres):

$$
I=\frac{m}{h^{2}}
$$

Interpretation of BMI values was carried out in accordance with WHO recommendations (18).

Arterial hypertension (AH) was observed in patients with RCC and study participants who had a history of hypertension, or a persistent increase in blood pressure values of more than $140 / 90 \mathrm{~mm} \mathrm{Hg}(19)$.

\section{Statistical analyses}

All data are presented as frequency in percent (\%). To assess the risk of developing RCC in the presence of a number of predisposing factors, odds ratios (ORs) were calculated with 95\% confidence intervals (95\% CI). In each case, confidence intervals were calculated for the OR. The chances were considered statistically significant if the unit did not fall within the confidence interval.

\section{RESULTS}

\section{Smoking}

Among the study group patients, 245 (49.0\%) were identified as smokers, and of these, there were 211 men (73.8\%) and 34 women $(15.9 \%)$. In the control group (regional population), 285 (33.2\%) were smokers, including 208 men (49.2\%) and 77 women (17.7\%). The data obtained indicate a statistically significant $(\mathrm{p}<0.05)$ prevalence of smoking among patients with RCC. This predominance is formed mainly by male smokers in the study group (smoking rate was 1.5 times higher than in the control group men). For females, there were no significant differences in smoking rates in the compared groups. Age-specific analysis of the prevalence of smoking in the compared groups revealed a significant predominance of smokers among men in the study group. Additionally, compared to the control group, among men with RCC in the age groups 35-39, 45-49, 50$54,55-59$, and 60-64 years and women aged 35-39 years, the prevalence of smoking was significant $(\mathrm{p}<0.05)$ (Figure 1$)$.

Regarding the quality of tobacco products used by patients with RCC, it was found that most of the patients who used tobacco smoked cigarettes: men $65.4 \%$, women $70.6 \% ; 3.3 \%$ of men and $0 \%$ of women smoked cigarettes; $2.8 \%$ of men and $0 \%$ of women smoked cigarettes; other kinds of tobacco products were used by $6.6 \%$ of men and $5.9 \%$ of women.

Among the control group, the majority of smokers had a smoking history of up to 10 years, and among those in the study group, the smoking history was 20-29 years. In this case, among patients with RCC compared with the control group, the proportion of people who had smoked for less than 10 years was much lower, and those who had smoked for more than 30 years were predominant.

For males, there were significant smoking differences in 2 subgroups: smoking experience of up to 10 years and smoking experience of 30-39 years. In the first subgroup, smoking experience in the study group was significantly lower (3.8 times), and in the second subgroup was 2.8 times higher $(\mathrm{p}<0.05)$.

Among women, significant differences in smoking experience were found in all subgroups. In the subgroup with smoking experience of up to 10 years, the proportion of women in the control group was 7.3 times higher than that of the study group, and in the subgroup with 10-19 years of experience, there was a similar trend with a difference in indices of 2.2. In subgroups with smoking experience of 20-29 years, $30-39$ years, and 40 years or more, the propor- 


\section{Male}

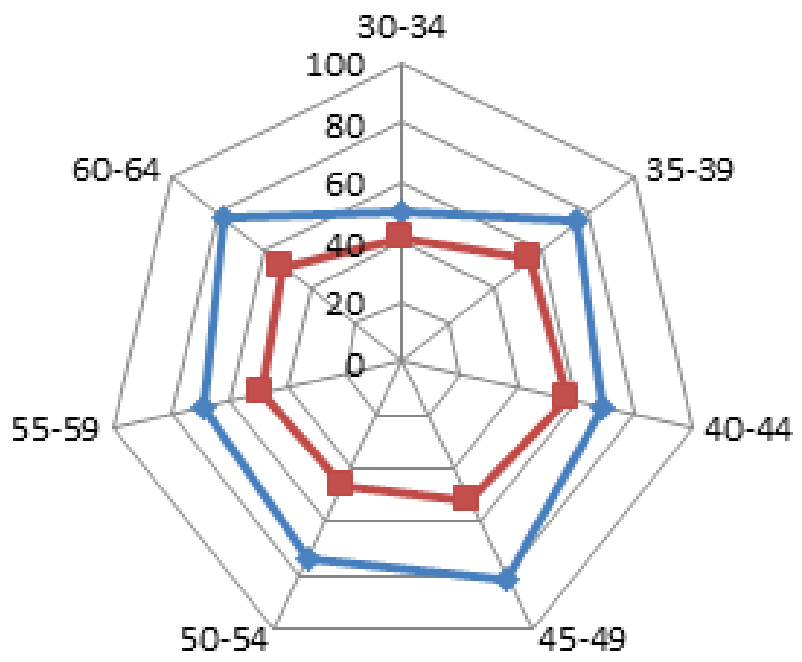

$\leadsto$ Study group $\quad \rightarrow$ Control group
Female

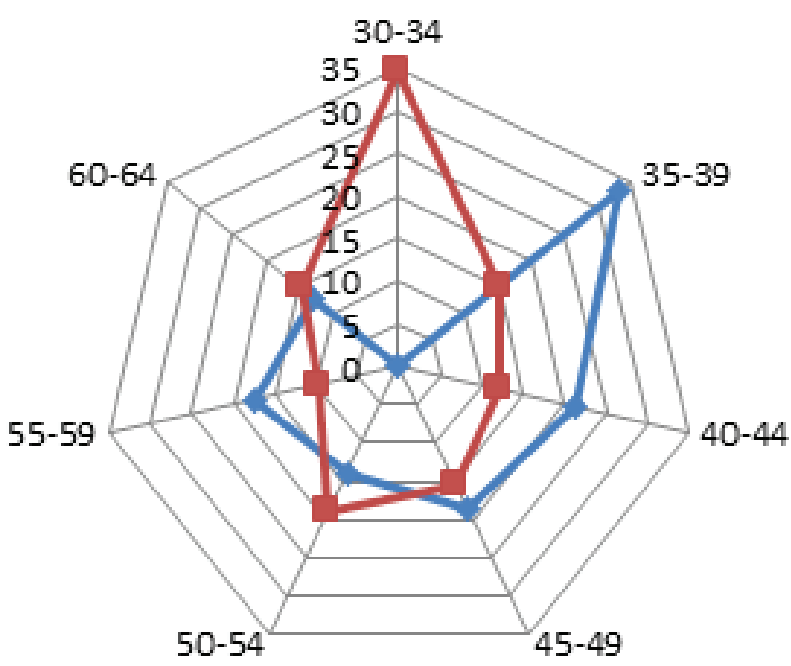

$\leadsto$ Study group $\rightarrow-$ Control group

Figure 1. Prevalence of smoking in men and women in the compared groups.

tion of women in the study group was much higher; 1.8 , 2.9 , and 7.9 times, respectively, than a similar indicator in the control group.

Furthermore, $47.3 \%$ of patients with RCC smoked 10 to 20 cigarettes a day. The same number of cigarettes smoked was smoked by men with RCC, and among women surveyed, the prevalence of smoking was up to 10 cigarettes a day (50.0\%). Comparative analysis of the number of smoked cigarettes did not reveal significant differences for this indicator for the groups compared.

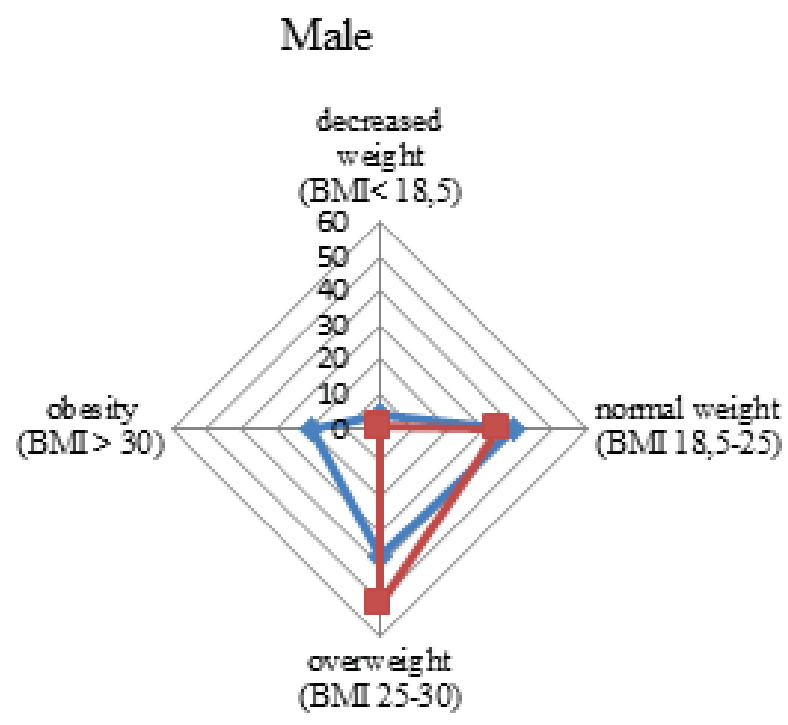

$\longrightarrow$ Study group - Control group

Figure 2. BMI distribution of men and women in the compared groups.

\section{Obesity}

Compared with the control group, we found two statistically significant trends in our age-specific analysis of BMI: the prevalence of men with normal body weight (BMI 18.5-25) and the reduced in overweight (BMI 25-30) among RCC patients aged 35-39, 40-44 and 50-54 years (Figure 2).

Age-specific analysis of BMI in the compared groups of women revealed a 4.2 times predominance of persons with excess weight in the 30-34 years age group (BMI 25-30). In

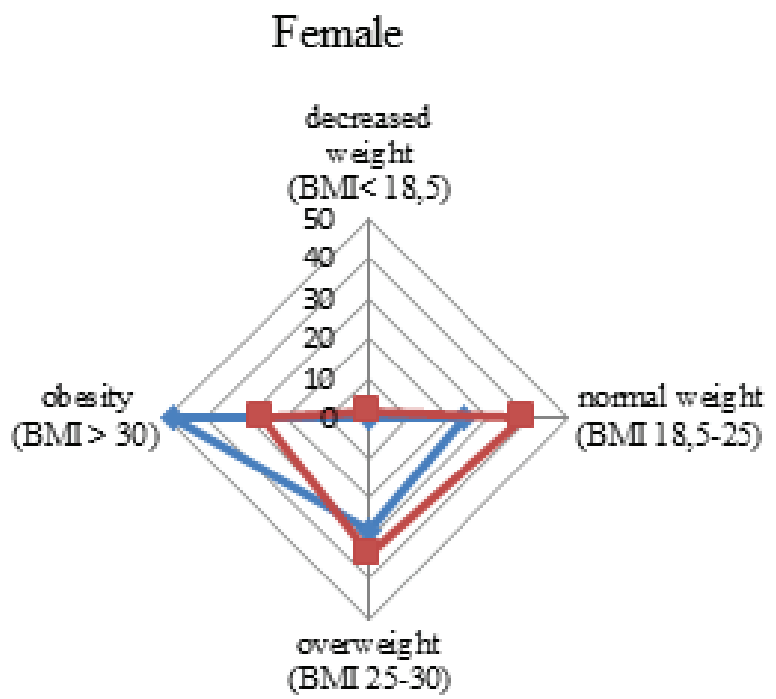

$\longrightarrow$ Study group $\rightarrow$ Control group 


\section{Male}

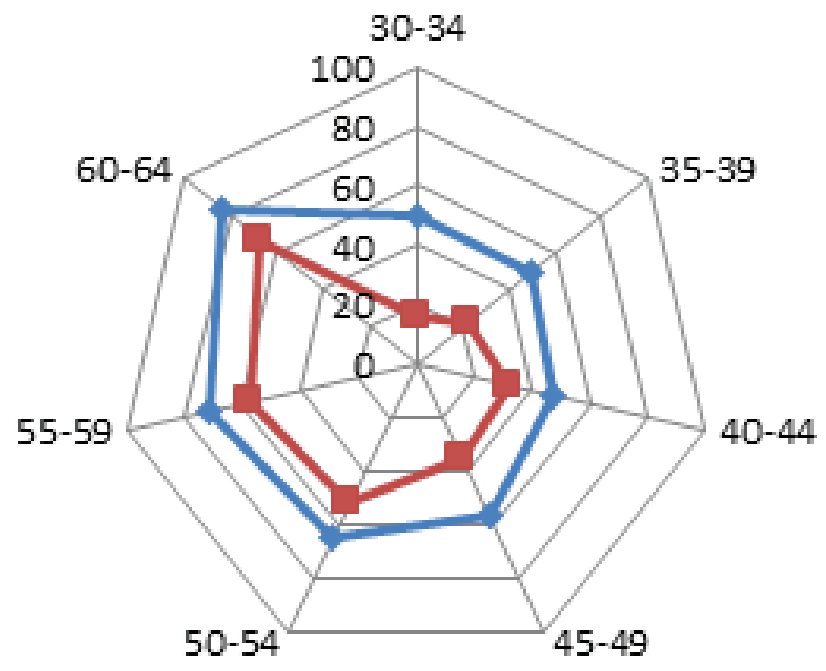

$\multimap$ Study group $\quad \rightarrow-$ Control group

Figure 3. Prevalence of $\mathrm{AH}$ in men and women in the compared groups.

the 35-39 years age of the study group, there were $31.6 \%$ more people with a body mass deficit $(\mathrm{BMI}<18.5), 21.7 \%$ fewer women with normal body weight (BMI 18.5-25) and $18.3 \%$ more obese people (BMI $>30)$ than in the control group. In the 40-44 years age in the study group, the number of persons with normal body weight was reduced by $43.8 \%$, and there were $39.7 \%$ more women with obesity than in the control group. In the 60-64 years age group, there were $18.4 \%$ fewer overweight women in the study group and an $18.9 \%$ increase in the number of obese people compared to the control group. Despite the multidirectional character of age-specific trends, the final data show that in comparison with the control group, there was a predominance of obese women in the study group and a decrease in the proportion of people with normal body weight (Figure 2).

\section{Arterial hypertension}

In the study group, the average prevalence of arterial hypertension $(\mathrm{AH})$ was $66.1 \%$ and $75.7 \%$ among men and women, respectively. In general, the prevalence of hypertension in patients of both sexes with RCC was $70.2 \%$, which was significantly higher than the $43.4 \%$ in the control group $(\mathrm{p}<0.05)$. The prevalence of hypertension tended to increase with age among both men and women.

Age-specific analysis of the prevalence of hypertension in men and women in the compared groups is shown in Fig. 3. For both sexes, there was a statistically significant prevalence $(\mathrm{p}<0.05)$ of hypertension among patients with RCC in age groups 35-39, 40-44, and 45-49 and in men with RP at ages 30-34 and 60-64.

\section{Female}

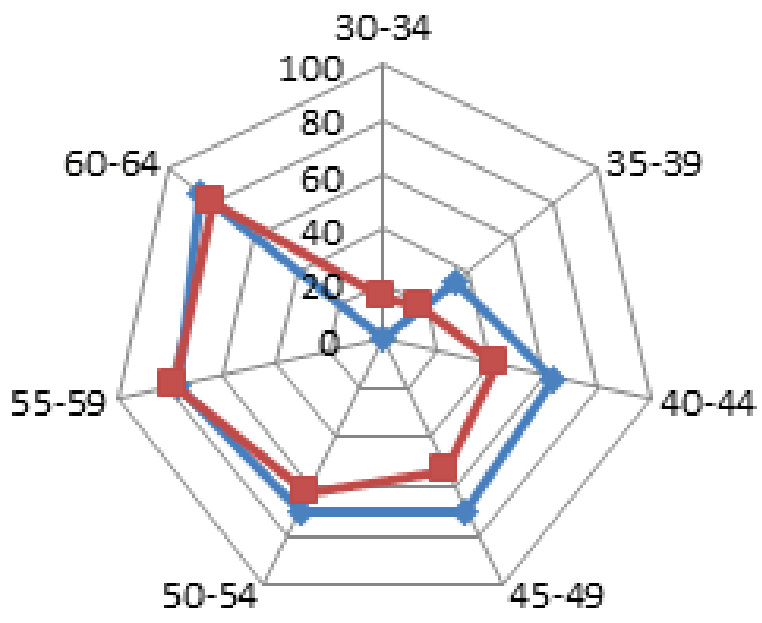

$\leadsto$ Study group $\rightarrow$ Control group

\section{Combination of risk factors}

The combination of all three risk factors for RCC was identified in $11.4 \%$ (13.6\% of men, $8.4 \%$ of women), smoking and obesity in $14.4 \%$ ( $16.1 \%$ of men, $12.1 \%$ of women), smoking and hypertension in $34.8 \%$ (58.3\% of men, $9.3 \%$ of women), and obesity and hypertension in $29.0 \%$ (17.8\% of men, $43.9 \%$ of women).

\section{Risk assessment of RCC development}

In assessing the impact of risk factors on the development of RCC in men, it was found that the likelihood of developing disease was 2.9 times higher among smokers and 3.3 times higher among patients with $\mathrm{AH}$. In women, the incidence of RCC increased by a factor of 2.6 in the presence of obesity and by 3.2 times with elevated BP fig-

Table 1. The ratio of the chances of developing RCC among participants of the region, depending on risk factor

\begin{tabular}{|c|c|c|c|c|}
\hline \multirow{2}{*}{ Risk factor } & \multirow{2}{*}{ Sex } & \multirow{2}{*}{ OR } & \multicolumn{2}{|c|}{$95 \%$ CI } \\
\cline { 4 - 5 } & & & $\begin{array}{c}\text { Lower } \\
\text { bound }\end{array}$ & $\begin{array}{c}\text { Upper } \\
\text { bound }\end{array}$ \\
\hline \multirow{2}{*}{ Smoking } & Male & $2.894^{*}$ & 2.091 & 4.007 \\
\cline { 2 - 5 } & Female & 0.881 & 0.566 & 1.369 \\
\hline \multirow{2}{*}{ Obesity } & Male & 1.494 & 0.998 & 2.238 \\
\cline { 2 - 5 } & Female & $2.621^{*}$ & 1.860 & 3.693 \\
\hline \multirow{2}{*}{ Arterial hypertension } & Male & $3.256^{*}$ & 2.378 & 4.458 \\
\cline { 2 - 5 } & Female & $3.232^{*}$ & 2.245 & 4.653 \\
\hline
\end{tabular}

Note: * - significant odds ratios. 
ures. There was no significant difference in the likelihood of developing RCC in men with obesity and in women who smoked (Table 1).

Among men with smoking as a risk factor, the risk of developing RCC was confirmed for 4 age groups: 45-49 (OR 5.313 (95\% CI 2.430-11.612)), 50-54 (OR 3.180 (95\% CI 1.606-6.297)), 55-59 OR 2.257 (95\% CI 1.077-4.731)) and 60-64 years (OR 3.135 (95\% CI 1.217-8.073)). For hypertension, a significant odds ratio of 2.4 times $(95 \% \mathrm{CI}$ 1.2-5.0) was found only for ages $45-49$ years. Among female patients, significant chances of developing RCC were found in obese patients in 2 age groups: 40-44 (OR 6.267 (95\% CI, 1.778-22.081)) and 60-64 years (OR 2.182 (95\% CI 1.044-4.559)).

\section{DISCUSSION}

From a medical and demographic point of view, Krasnoyarsk Territory is the largest part of the Russian Federation with a regressive type of population and gender disproportion (the prevalence of women is 14.5\%), in addition to high mortality among able-bodied people $(30.6 \%)$, most of whom are men (78.2\%). Oncological diseases make a significant contribution to the mortality of the working-age population in our region as the thirdmost common cause of death (20). The mortality from $\mathrm{RCC}$ is significant to the region's medical, demographic and economic losses for a number of reasons: against a background of high mortality (JV 4.54, in the Russian Federation, 3.43 per 100,000 population), low, active detection rates were $7.5 \%$ (RF $11.1 \%$ ), and early diagnosis of the disease was $46.2 \%$ (RF $55.8 \%$ ).

Using the analysis of major lifestyle risk factors for developing RCC, we demonstrated the prevalence of smoking in men in virtually all analysed age groups and for women with RCC at ages 35-39 years. According to the quality of tobacco products used by patients with RCC, our data are comparable with the results of regional and Russian $(15,16)$ sociological polls of the population: $59.8 \%$ of men smoke, and $81.5 \%$ of women use factory-produced cigarettes in Russia (in our study $65.4 \%$ and $70.6 \%$, respectively); $2.2 \%$ of men and $0.7 \%$ of women smoked cigarettes (our study; $3.3 \%$ and $0.0 \%$ ); $1.8 \%$ of men and $1.4 \%$ of women smoked cigarettes (our study; $2.8 \%$ and $0 \%$ ); and other kinds of tobacco products are used by $8.3 \%$ of men and $3.8 \%$ of women (our study $6.6 \%$ and $5.9 \%$ ). Compared to the regional population (control group), smoking experience was significantly higher among patients with RCC, which was confirmed by the prevalence in this group of people who smoked for more than 20 years and the proportion of people who smoked for less than 10 years.

Overall, $31.6 \%$ of patients with RCC were obese; women, $65.2 \%$ and men, $34.8 \%$. In the control group, the proportion of obese individuals was $20.0 \%$ (women, 66.3\%; men, 33.7\%). The most interesting and significant trend was revealed in the analysis of BMI, where compared with the control group, there was a predominance of obese females in the study group. No less important is the fact that this trend was formed mainly at the expense of age groups 40-44 and 60-64.

There was a prevalence of AH among men with RCC in almost all age groups and in women at younger ages (3539, 40-44, 45-49 years).

Still, the importance and actuality of combined risk factors for the development of RCC is present in the literature. For example, when smoking and obesity are combined, the gender significance of the factors increases; in men, the risk of developing the disease increases by $47.0 \%$, and in women by $33.9 \%$ (1). Krasnoyarsk residents have found that for men, risk factors such as smoking and hypertension (increased risk of developing RCC is 2.9 and 3.3 times, respectively) are more significant, and for women, obesity and hypertension (in 2.6 and 3.2 times respectively). All three risk factors are combined in $13.6 \%$ of men and in $8.4 \%$ of women with RCC.

\section{CONCLUSION}

A comprehensive analysis of the given risk factors for the development of RCC indicates that most attention should be paid to lifestyle-related factors: smoking, obesity and hypertension. On the other hand, these factors are preventable through primary and secondary prevention procedures, and they may be a useful tool for the screening and early diagnosis of RCC.

\section{CONFLICT OF INTEREST}

The authors declare no conflict of interest regarding this manuscript.

\section{REFERENCES}

1. IARC Monographs on the Evaluation of Carcinogenic Risks to Humans (Electronic resource). - Lyon, France: International Agency for Research on Cancer, 2011. http://monographs.iarc.fr/ENG/Monographs/ PDFs/index.php.

2. Guidelines on renal cell carcinoma (Electronic resource) / B. Ljungberg, N. Cowan, D. C. Hanbury (et al.). EuropeanAssociation of Urology, 2013. http:// www.uroweb. org/gls/pdf/10_Renal_Cell_Carcinoma_LR.pdf.

3. Cogliano VJ, Baan R, Straif K, et al. Preventable exposures associated with human cancers. J Natl Cancer Inst. 2011;103(24):1827-39.

4. Macleod LC, Hotaling JM, Wright JL, et al. Risk factors for renal cell carcinoma in the VITAL study. J Urol. 2013;190(5):1657-61. 
5. Hunt JD, van der Hel OL, McMillan GP, Boffetta P, Brennan P. Renal cell carcinoma in relation to cigarette smoking: meta-analysis of 24 studies. Int J Cancer. 2005;114(1):101-8.

6. Adams KF, Leitzmann MF, Albanes D, et al. Body size and renal cell cancer incidence in a large US cohort study. Am J Epidemiol. 2008;168(3):268-77.

7. Renehan AG, Tyson M, Egger M, Heller RF, Zwahlen M. Body-mass index and incidence of cancer: a systematic review and meta-analysis of prospective observational studies. Lancet. 2008;371(9612):569-78.

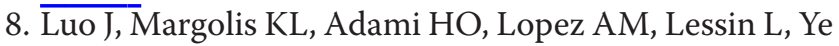
W; Women's Health Initiative Investigators. Body size, weight cycling, and risk of renal cell carcinoma among postmenopausal women: the Women's Health Initiative (United States). Am J Epidemiol. 2007;166(7):752-9.

9. Klinghoffer Z, Yang B, Kapoor A, Pinthus JH. Obesity and renal cell carcinoma: epidemiology, underlying mechanisms and management considerations. Expert Rev Anticancer Ther. 2009;9(7):975-87.

10. Moore SC, Chow WH, Schatzkin A, et al. Physical activity during adulthood and adolescence in relation to renal cell cancer. Am J Epidemiol. 2008;168(2):149-57.

11. Corrao G, Scotti L, Bagnardi V, Sega R. Hypertension, antihypertensive therapy and renal-cell cancer: a metaanalysis. Curr Drug Saf. 2007;2(2):125-33.

12. Setiawan VW, Stram DO, Nomura AM, Kolonel LN, Henderson BE. Risk factors for renal cell cancer: the multiethnic cohort. Am J Epidemiol. 2007;166(8):932-40.
13. Gago-Dominguez M, Castelao JE, Yuan JM, Ross RK, Yu MC. Lipid peroxidation: a novel and unifying concept of the etiology of renal cell carcinoma (United States). Cancer Causes Control. 2002;13(3):287-93.

14. Sharifi N, Farrar WL. Perturbations in hypoxia detection: a shared link between hereditary and sporadic tumor formation? Med Hypotheses. 2006;66(4):732-5.

15. Report on the results of a sociological survey to assess public opinion on the quality of diagnostic services and coverage of educational information within the long-term targeted program "Prevention and control of socially significant diseases" for 2011-2013. - Krasnoyarsk: The Locomotive of Innovation, 2011. - Section IV. - $182 \mathrm{sec}$.

16. Global survey of the adult population on tobacco consumption. Russian Federation, 2009. Country report. M.: (B.I.), 2009. - 171 p.Parkin, D. M.

17. Parkin DM, Boyd L, Walker LC. 16. The fraction of cancer attributable to lifestyle and environmental factors in the UK in 2010. Br J Cancer. 2011;105 Suppl 2:S77-81.

18. Global Database on Body Mass Index (Electronic resource) // WHO. - URL : http://apps.who.int/bmi/index. jsp?introPage=intro.html.

19. The ESC Textbook of Cardiovascular Medicine / eds. A. J. Camm, T. F. Luscher, P. Serruys. - USA : WileyBlackwell, 2006. - $1136 \mathrm{p}$.

20. State report on the health of the population and the health of the Krasnoyarsk Territory in 2012. Krasnoyarsk:KKMIATS, 2013 - 344 p. 